\title{
PRINCIPY SPOLEČENSKY PŘÍNOSNÉHO MUZEA NA PŘíKLADU GALERIE STŘEDOČESKÉHO KRAJE V KUTNÉ HOŘE ${ }^{1}$
}

\section{VĚRA PINNOY}

\section{ABSTRAKT/ABSTRACT:}

Text se zabývá myšlenkou společensky prospěšného muzea a jeho vlivu na současnou muzejní praxi. Poukazuje na rozdíl mezi tradičním a společensky odpovědným muzeem a popisuje aplikaci společensky odpovědného přístupu do konkrétní muzejní praxe Galerie Středočeského kraje v Kutné Hoře. Hlavní pozornost je věnována činnosti Lektorského centra GASK jako jedné ze stěžejních pozic uskutečňování inkluzivního přístupu a společenského poslání galerie, zejména potom třem projektům - „Místo $v$ depozitáríi, „Věznice: místo pro uměni" a „Umění spojení“, zaměřeným na spolupráci s místní komunitou a vyloučenými skupinami.

Principles of a socially beneficial museum on the example of the Gallery of the Central Bohemian Region, Kutná Hora

This article discusses the idea of a socially beneficial museum and its influence on the current museum practice. It points out the difference between traditional museums and socially responsible museums, and describes the application of a socially responsible

1 Tento článek vychází z bakalářské práce PINNOY, Věra. Galerie Středočeského kraje jako společensky prospěšná instituce. Brno: Masarykova univerzita, Filozofická fakulta, Ústav archeologie a muzeologie, 2017. 74 s. Bakalářská diplomová práce. Vedoucí práce Mgr. Lucie Jagošová, DiS. approach in the museum practice of the Gallery of the Central Bohemian Region in Kutná Hora (GASK). The main focus is on the activities of the gallery's Lecture Centre as one of the key elements in the employment of the inclusive approach and social agenda of the gallery and, in particular, on three projects: Place in a Depositary, Prison: A Place for Art and The Art of Connection, based on the collaboration with the local community and socially deprived groups.

\section{KLÍČOVÁ SLOVA/KEYWORDS:}

společensky prospěšné muzeum společenská odpovědnost kulturních institucí - sociální inkluze - Galerie Středočeského kraje - „Umění spojeni““ - „Věznice: místo pro uměni“ - „Místo

$v$ depozitáríi

socially beneficial museum social responsibility of cultural institutions - social inclusion Gallery of the Central Bohemian Region - The Art of Connection Prison: A Place for Art - Place in a Depositary

\section{Východiska pro transformaci}

Pojem „společensky přínosné muzeum" je třeba chápat v kontextu celkového vývoje muzejní praxe, která za poslední půlstoletí došla razantních změn. Kulturní sektor a zejména muzea byla tradičně vnímána jako elitářské prostředí určené vzdělané elitě národa, která při jejich zakládání nemusela řešit problém s demokratizací kultury, protože kultura sloužila právě pouze potřebám sociálně silných, těch nejvzdělanějších a nejmajetnějších. Mnoha lidmi jsou dodnes vnímána jako „exkluzivní“ instituce, které přiznávají hodnotu jen určitým typům témat a znalostí. ${ }^{2}$ Většina muzeí je i v současnosti zaměřená pouze na interní procesy budování sbírek, jejich dokumentaci, vystavování a interpretaci vnějšího světa bez jiného společenského cíle než sloužit vědění a kráse pro ně samotné. ${ }^{3}$ Vyhýbají se, jak z morálních, tak z praktických důvodů, širší angažovanosti ve světě, v němž coby společenské instituce působí. ${ }^{4}$ Muzea by ovšem neměla nadále reflektovat pouze zájmy úzké skupiny lidí, ale naopak odrážet hojnost, rozmanitost a hodnoty různých komunit. Podle Richarda Sandella ${ }^{5}$ faktory jako globální hnutí za lidská práva, sociální aktivismus, populační

\footnotetext{
2 MILANO, Cristina Da. Museums as Agents of social inclusion [online]. 2013, [cit. 2017-05-16]. Dostupný z www: < http://museummediators.eu/ wp-content/uploads/2013/09/Museums-as-agentsof-social-inclusion_DaMilano.pdf $>$.

3 DODD, Jocelyn. The socially purposeful museum. Museologica Brunensia, 2015, č. 2, s. $28-32$.

4 JANES, Robert R. Museums in The troubled world, Oxon [online]. 2009, s. 13 [cit. 2017 -04-26]. Dostupný z www: <http://documents. routledge-interactive.s3.amazonaws. com/9781138906372/2._Its_a_Jungle_in_Here. pdf $>$.

5 Profesor Richard Sandell, Univerzita v Leicesteru, UK, jeho klíčové práce [online]. [cit. 2017-04-23]. Dostupné z www: <http://www2. le.ac.uk/departments/museumstudies/about-the school/people/Prof\%20Richard\%20Sandell/ Key_publications $>$.
} 
změny v západním světě, ale také fakt, že většina kulturních institucí je financována $\mathrm{z}$ veřejných peněz, zvyšují nároky na odpovědnost veřejných institucí, jež by se mohly dalším ignorováním společenských potřeb vystavit riziku ztráty společenského významu.

Transformace muzeí a galerií ve společensky př́nosné instituce je konfrontuje $s$ potřebou změn v jejich filozofii, hodnotách, cílech a postupech. Neexistuje jeden recept, jak proměnit všechna muzea a galerie na společensky odpovědné instituce přispívající k sociální inkluzi, v muzejní práci ovšem existuje řada cest, které reagují na sociální výzvy a problémy společnosti.

\section{Společensky přínosné muzeum}

V zahraničních materiálech se pro označení kulturních institucí, které uplatňují společensky odpovědný př́stup, setkáváme s pojmy „socially purposeful“" nebo „socially responsible" museum, $v$ češtině se užívají termíny „sociálně“ či „společensky odpovědná, př́inosná či prospěšná" muzea, jež vyjadřují v zásadě totéž.

Východisko pro koncept společensky přínosného muzea popisuje koncept „sociální inkluze," který byl rozvinut v rámci dlouholetého výzkumu Výzkumného centra pro muzea a galerie (The Research Centre for Museums and Galleries ${ }^{6}$ RCMG) při Škole muzejních studií (School of Museum Studies) Leicesterské univerzity ve Velké Británii. Pro jeho pochopení je nutné v daném kontextu definovat pojmy sociální inkluze neboli začleňování a sociální exkluze neboli vyloučení. Sociální exkluze označuje celý proces úplného nebo

6 Museum studies: RCMG. In University of Leicester [online]. [cit. 2017-03-20]. Dostupný z www: <http://www2.le.ac.uk/departments/ museumstudies/rcmg $>$. částečného vyřazení jednotlivce či celé skupiny osob ze sociálního, politického, ekonomického či kulturního systému, jež jsou rozhodující pro sociální integraci do společnosti. ${ }^{7}$ Může mít rozměr ekonomický, sociální, politický nebo kulturní ${ }^{8}$ a její základní charakteristikou je vzájemná propojenost a závislost těchto aspektů. Např́íklad nízké vzdělání může do budoucna vést $\mathrm{k}$ nízkému prríjmu, nezaměstnanosti, nekvalitnímu bydlení, které může způsobit zdravotní potíže, ztížený př́stup $\mathrm{k}$ finančním zdrojům, který dále může zapř́ičinit rozvoj černé ekonomiky či kriminality. Právě tato vzájemná provázanost všech dimenzí sociální exkluze umožňuje i muzeím a galeriím účast na konceptu sociální inkluze. Sociální inkluze představuje naopak proces, který vrací sociálně vyloučeného člověka zpět do běžného života ke zdrojům, které jsou nezbytné ke spoluúčasti na ekonomickém, sociálním a kulturním životě společnosti, aby mohl dosáhnout životní úrovně, považované ve společnosti, kde žije, za standardní. ${ }^{9}$

Muzea a galerie dnes již běžně hledají způsoby, jak se stát přístupnější skupinám, které dlouhodobě nejsou zastoupeny v profilu jejich návštěvníků, a odhalit př́ičiny toho, proč muzea nenavštěvují. Na této úrovni je již pojmenována řada bariér a způsobů

\footnotetext{
7 WALKER, Alan a Carol WALKER. Britain Divided: The Growth of Social Exclusion in the 1980s and 1990s. London: Child Poverty Action Group, 1997. $308 \mathrm{~s}$.

8 Podrobnější vymezení dimenzí sociální exkluze viz MAREŠ, Petr a Tomáš SIROVÁTKA. Sociální vyloučení (exkluze) a sociální začleňováni (inkluze) - koncepty, diskurz, agenda [online]. Praha: Sociologický ústav AV ČR, 2008, s. 274275 [cit. 2017-05-18]. Dostupný z www: <http:// www.inkluzivniskola.cz/sites/default/files/ uploaded/Socialni_vylouceni_exkluze_a_socialni_ zaclenovani_inkluze.pdf $>$.

9 JAGOŠOVÁ, Lucie. Muzea a sociální inkluze. In Muzea a sociálně znevýhodnění: Sborník ze semináře 19.-20. 6. 2013. Hodonín: Masarykovo muzeum v Hodoníně, 2014, s. 22.
}

jak je překonat. ${ }^{10} \mathrm{~V}$ posledních letech se věnuje stále větší pozornost fyzické dostupnosti, tedy prrístupu do budovy a orientace ve vnitřních prostorách muzea, smyslové a intelektuální dostupnosti muzejních prezentací, informovanosti potenciálního publika o nabízených programech muzea, vhodně nastavené politice zpoplatnění vstupů a otevírací doby, jež jsou pojmenovány jako nejčastější „praktické bariéry“ v návštěvnosti. ${ }^{11}$ Je třeba zdưraznit zejm. kulturní a emocionální bariéry a skutečnost, jak může kulturní inkluze, ve které hrají roli právě muzea a galerie ovlivňovat další, tedy ekonomický, sociální a politický rozměr sociálního vyloučení. Je zřejmé, že muzea a galerie nemohou sama o sobě snížit kriminalitu, nezaměstnanost či intoleranci, nicméně výzkumy $\mathrm{RCMG}^{12}$ ukazují až překvapující podíl účasti, jaký mohou muzea a galerie na tomto poli mít. Jocelyn Dodd a Richard Sandell z Výzkumného centra pro muzea a galerie v Leicesteru popisují tři úrovně, na kterých mohou muzea a galerie přispět k sociální inkluzi - individuální, komunitní a společenskou. ${ }^{13}$

10 JAGOŠOVÁ, Lucie. Muzea a sociální inkluze: Muzea a bariéry. In Muzea a sociálně znevýhodnění: Sborník ze semináře 19.-20. 6. 2013. Hodonín: Masarykovo muzeum v Hodoníně, 2014, s. 27.

11 KESNER, Ladislav. Marketing a managment muzeí a památek. 1. vyd. Praha: Grada Publishing, 2005. 304 s

12 Vizí RCMG je provádět výzkum, který

bude zdrojem informací a rozvoje kreativního muzejního myšlení, politiky i praxe. Staví na rozvoji spolupráce a partnerství na mezinárodní úrovni za účelem podpory muzeí, aby se staly dynamičtějšími, inkluzivními a společensky prínosnými institucemi. Hlavní výzkumná témata RCMG zahrnují: procesy učení v muzeích, aktivní zapojení muzeí do otázek sociální spravedlnosti, nové přístupy v rozvoji etického myšlení a praxe, zapojení veřejnosti do současných společenských témat prostřednictvím sbírek a výstav. Museum studies: RCMG. In University of Leicester [online]. [cit. 2017-03-11]. Dostupný z www: < http:// www2.le.ac.uk/departments/museumstudies/ remg $>$.

13 DODD, Jocelyn a Richard SANDELL.

Social roles and responsibilities. In Including museums: perspectives on museums, galleries and social inclusion [online]. Leicester: University of Leicester, Department of Museum Studies, 
U jednotlivců může inkluzivní prrístup muzea přinést pozitivní výsledky hlavně prostřednictvím programů a workshopů, kde se pracuje „face to face“ $s$ konkrétními lidmi, a to $\mathrm{v}$ podobě posílení sebeúcty a kreativity jednotlivce, získání nových dovedností a sebevědomí. Takové výsledky mohou potom pomoci lidem $\mathrm{v}$ př̀konání rùzných forem znevýhodnění či vyloučení. ${ }^{14}$ Muzea a galerie jsou ideálním prostorem, který nejen inspiruje a probouzí kreativitu, ale může vyvolávat i pocit bezpečí, podpory a nabízet některým lidem přiležitost $\mathrm{k}$ osobnímu rozvoji, který jim není $\mathrm{v}$ jejich životě, at už $\mathrm{z}$ jakéhokoliv důvodu, umožněn. $\mathrm{Na}$ této úrovni je třeba spolupracovat s dalšími organizacemi (jako např. výchovnými ústavy, nízkoprahovými kluby, domovy pro seniory ad.), které sdružují potenciální účastníky programů. Zapojení samotných účastníků do rozhodování o tom, jak by měla muzea co nejlépe vyhovět jejich potřebám, bývá potom důležitou podmínkou úspěšnosti programů. Na komunitní úrovni mohou muzea působit jako katalyzátory pro sociální regeneraci, podporovat komunity $\mathrm{v}$ jejich sebeurčení, rozvíjet jejich důvěru ve vlastní dovednosti, aby převzaly větší kontrolu nad svými životy i nad oblastmi, ve kterých žijí. Na celospolečenské úrovni má potom zapojení komunit do života muzeí, začlenění a prezentace jejich prací ve sbírkách, potenciál šírit toleranci a vzájemný respekt, měnit postoje celé společnosti a napadat stereotypy. ${ }^{15}$ Takové

2001, s. 25 [cit. 2017-02-26]. Dostupný z www: <https://www2.le.ac.uk/departments/ museumstudies/rcmg/projects/small-museumsand-social-inclusion/Including\%20museums.pdf $>$.

14 MÜLLEROVÁ, Magdalena, Ondřej KAŠPÁREK a Věra FRAJTOVÁ. Umělci pro společnost: Př́́klady kulturních projektů v oblasti sociální inkluze.

1. vyd. Praha: Česká kancelář programu Culture nákladem Institutu umění - Divadelního ústavu, 2010. 88 s.

15 DODD, Jocelyn a Richard SANDELL. Social roles and responsibilities. In Including ambice měl v našem prostředí např. projekt „Věznice, místo pro uměni““. ${ }^{16}$

Další související otázkou může být zavedení inkluzivních postupů do klíčových oblastí ve správě sbírek, a to při jejich vytváření, dokumentaci a konzervaci sbírkových předmětů. ${ }^{17}$ Sbírkotvorná činnost je tradičně vnímána jako neutrální a nestranná. Shromaždování sbírkových předmětů, znalostí a informací s nimi spojených, jejich formování a interpretace však nejsou dle Jocelyn Dodd a Richarda Sandela ani nestranné, ani objektivní a v praxi mohou být optikou inkluzivního přístupu hluboce „exkluzivní“. Otázkou autorů je, jak by se sbírky změnily, kdyby byl dán prostor i širšímu nespecializovanému publiku ovlivnit názor, co je důležité do sbírek zařadit. Autoři se domnívají, že je třeba v tomto směru získat jasnější představu o tom, co by současné a budoucí publikum ve sbírkách chtělo. Aktivní príistup založený na spolupráci a konzultacích $s$ různými zainteresovanými stranami s cílem poznat jejich zájmy, potřeby, touhy a zapojit je do rozhodovacího procesu může $\mathrm{v}$ tomto směru znamenat určitý posun vpřed.

museums: perspectives on museums, galleries and social inclusion [online]. Leicester: University of Leicester, Department of Museum Studies, 2001, s. 24-28 [cit. 2017-02-26]. Dostupný z www: <https://www2.le.ac.uk/departments/ museumstudies/rcmg/projects/small-museums and-social-inclusion/Including\%20museums.pdf $>$.

16 Projekt Ondřeje Horáka a Martiny

Rekové, 2011 viz Věznice: místo pro umění. In PINNOY, Věra. Galerie Středočeského kraje jako společensky prospěšná instituce. Brno: Masarykova univerzita, Filozofická fakulta, Ústav archeologie a muzeologie, 2017, s. 32-40. Bakalářská diplomová práce.

17 DODD, Jocelyn a Richard SANDELL. Collections Management and Inclusion. Conservation and inclusion. In Including museums: perspectives on museums, galleries and social inclusion [online]. Leicester: University of Leicester, Department of Museum Studies, 2001, s. 80-87 [cit. 2017-05-16]. Dostupný z www: <https://www2.le.ac.uk/departments/ museumstudies/rcmg/projects/small-museumsand-social-inclusion/Including\%20museums.pdf > .
Další výzvou je ve sbírkotvorné činnosti proces dokumentace sbírek, jež nese v kontextu sociální inkluze značný potenciál. Velmi záleží na tom, jakým způsobem generujeme informace, jaké termíny použijeme v určitém kontextu a jaké vztahy mezi jednotlivými předměty vyzdvihneme. Pokud v této fázi systém selže, může představovat jednu z největších překážek inkluzivní praxe. Pokud je ovšem na poli dokumentace práce dobře odvedena, může být nesmírně přínosná pro různorodé publikum.

\section{Rozdíl mezi tradičním}

a společensky přínosným muzeem ${ }^{18}$ je obrovský. Společensky př́nosné muzeum se aktivně ujímá své společenské role a svou prací přispívá k tvorbě živé, vstřícné a spravedlivější společnosti. V partnerské spolupráci s řadou organizací se snaží naplňovat své cíle nejen v kulturním sektoru, ale také - což je důležitější - mimo něj. Coby hodnotově zaměřená organizace se snaží šírit progresivní společenské hodnoty, jako jsou sociální pohoda, rovnoprávnost a spravedlnost. Odhaluje a staví se proti diskriminaci a intoleranci všeho druhu a ve spolupráci s komunitami se snaží pochopit a vyvracet negativní a předpojaté názory. Je místem, kde jsou přijímány odlišnosti - ať už kulturní, sexuální, zdravotní či etnické - a kde lze zkoumat lidský život a kulturu, minulou, současnou i budoucí, v celé její bohatosti.

Muzeum je fórum - živé, čilé, angažující se, podnětné a rušné, na hony vzdálené tichým a ponurým muzejním galeriím minulosti. Je místem pro dialog a debatu, kde jsou ideje spíše propustné než věčné, místem objevování

18 Pro shrnutí zde uvádím ve volném překladu rozdíl mezi tradičním a společensky odpovědným muzeem, jež zformulovala Jocelyn Dood, ředitelka RCMG, ve svém článku The socially purposeful museum - viz Museologica Brunensia, 2015, č. 2, s. $28-32$. 
a rozvíjení světonázorů. Vědění tu není něčím, co mohou vytvářet jen znalci, akademici a kurátoři. Cení se tu celoživotní a holistické přístupy $\mathrm{k}$ učení. Je podporována praxe participace a spolutvorby a komunity jsou zvány $\mathrm{k}$ tomu, aby se podílely na vytváření nových hodnot. Jde o praktickou, sdílenou zkušenost založenou na podrobných konzultacích mezi muzeem a jeho komunitami. Muzeum ochotně vstřebává poznatky z komunit, s nimiž pracuje, je otevřené novým způsobům myšlení, konání, bytí a vnímání.

Vztah s publikem je jedním z hlavních rozdílů mezi společensky přínosným muzeem a jeho předchůdci. Návštěvníci už nejsou pasivními „houbami“ nasávajícími vědomosti a informace, které jim muzeum předkládá, ale aktivními strůjci svého vlastního vzdělání, „schopnými konstruovat své vlastní významy, které se mohou radikálně lišit od významů zamýšlených při tvorbě projektư'. Reagují na to, co v muzeu vidí, slyší a cítí. Do muzea přinášejí své vlastní myšlenky, názory, postoje a emoce, jejichž aktivní ohledávání se stává součástí muzejního zážitku. Je to oboustranný vztah založený na vzájemném sdílení a objevování, nikoli vztah diktovaný muzeem. Muzeum oslovuje široké spektrum lidí, nejen úzkou výseč společnosti. V publiku se odráží společenská diverzita: mezi návštěvníky jsou osoby různého věku, pohlaví, vzdělání, s různými životními zkušenostmi, kulturou, náboženským vyznáním, sexuálními preferencemi i zdravotním znevýhodněním. Muzeum už není odtržené od společnosti, ale je součástí jejího běžného života. Není to odlehlé, zřídka navštěvované místo, ale místo každodenního setkávání. Společensky zodpovědné muzeum tedy hraje ve společnosti plnohodnotnou a nepostradatelnou roli. I nadále se zabývá sběrem, dokumentací, vystavováním a interpretací, činí tak ale se záměrem, který přímo souvisí $s$ jeho pozicí ve společnosti. Ohniskem jeho koncepce je vztah $\mathrm{k}$ jednotlivcům a komunitám mimo muzeum.

\section{Galerie Středočeského kraje (GASK) jako společensky přínosná galerie: případová studie}

Každé muzeum může reagovat na sociální problémy a potřeby společnosti svým specifickým způsobem, který je mu vlastní a nejpřirozenější. Promítá se do něj ne jen její zaměření, lokace či priority nastavené kurátorským týmem a vedením, ale také historie muzea, sociální, kulturní a politické podhoubí, ze kterého vzešly jeho sbírky, a hlavně vůle muzejních pracovníků třeba i k malým posunům a změnám, jež následně vytvoří půdu pro inovativní pohledy vedoucí $\mathrm{k}$ úplně novému uchopení již zaběhnutých myšlenkových a pracovních postupů.

\section{GASK již od počátku svého} fungování v Kutné Hoře usilovala v rámci svých možností o co největší zpřístupnění svých prostor a sbírek se zohledněním různých specifických potřeb návštěvníků, at už ve smyslu bezbariérového přístupu do všech výstavních prostor, přehledného orientačního systému na stěnách galerie či vytvoření haptických přepisư ${ }^{19}$ pěti významných děl, jež jsou spolu s popisem $v$ Braillově písmu umístěny pod originálními díly. ${ }^{20}$ V původní stálé expozici byla

\footnotetext{
19 Jednotlivá díla byla převedena do speciální matrice a vytištěna do plastových fólií spolu s textem v Braillově písmu. Z přepisu lze poznat kompozici díla i některé detaily. Na pokladně GASK potom bylo možno zakoupit haptické reliéfní pohlednice těchto děl.

20 Tento výstavní program pro nevidomé byl počinem Ondřeje Horáka, tehdejšího vedoucího LC GASK, a v současné době se pracuje na jeho vylepšení a rozšíření.
}

umístěna také zvuková instalace, ${ }^{21}$ která nevidomým zprostředkovala dojem z unikátního prostoru jezuitské koleje.

Další rovinu společensky odpovědného přístupu galerie můžeme vnímat i v netradičních kurátorských přístupech, které nám mohou pomoci pochopit širší souvislosti našich dějin i vlastních životů, což můžeme vnímat jako jednu z priorit společensky odpovědného muzea. Obě stálé expozice „Sbírka 123/Stopy historie v akvizicích“22 Marie Bergmanové a „Stavy mysli/Za obrazem“23 Richarda Druryho, jež byly doposud v GASK prezentovány, překonávají tradiční koncepci stálých sbírek zaměřených většinou na nejcennější díla ilustrující dějiny umění vybraného období. Zejména druhá z nich, uspořádaná do jedenadvaceti dvojic zdánlivě opozitních stavů mysli zhmotněných uměleckými díly, poskytuje návštěvníkům velmi podnětné emoční a myšlenkové prostředí a lektorskému centru GASK (dále jen LC GASK) jako jedné ze stěžejních pozic uskutečňování inkluzivního prrístupu a společenského poslání galerie potom obrovský prostor v práci s veřejností.

\section{LC GASK vzniklo v roce 2009} a nejen díky velkoryse navrženým prostorám, určeným právě pro jeho potřeby, začalo velmi dynamicky rozvíjet svoje aktivity. V současné době jeho agendu

\footnotetext{
21 Zvuková instalace Tomáše Vaňka. Pro zprostředkování prostorového dojmu zde byl zachycen zvuk procházejícího koně a projíždějící motorky.

22 Sbírka 123 / Stopy historie v akvizicích. In PINNOY, Věra. Galerie Středočeského kraje jako společensky prospěšná instituce. Brno: Masarykova univerzita, Filozofická fakulta, Ústav archeologie a muzeologie, 2017, s. 24-25. Bakalářská diplomová práce.

23 Stavy mysli / Za obrazem. In PINNOY, Věra. Galerie Středočeského kraje jako společensky prospěšná instituce. Brno: Masarykova univerzita, Filozofická fakulta, Ústav archeologie a muzeologie, 2017, s. 25-27. Bakalářská diplomová práce.
} 
zpracovává vedoucí a dvě lektorky $\mathrm{s}$ vysokoškolským pedagogickým vzděláním na plný pracovní úvazek, na poloviční úvazek potom lektorka se vzděláním v oboru sociální práce a muzeologie zaměřená na programy se sociálním přesahem a na tvorbu strategie rozvoje společenského poslání GASK. LC GASK od svých počátků začalo kromě již tradičních aktivit, ${ }^{24}$ jejichž cílem je „podněcovat veřejnost, aby výtvarné umění vnímala jako přirozenou součást svého života“", ${ }^{25}$ rozvíjet své společenské poslání i na jiné úrovni.

Za významný krok, který se vymyká dnes již „běžným způsobům" zohlednění různých forem znevýhodnění a speciálních potřeb návštěvníků, lze považovat zejména aktivity LC GASK, jež se od svého vzniku systematicky snaží prostřednictvím umění přispět $\mathrm{k}$ pochopení a uvědomělejšímu přistupu ke společenským problémům mimo kulturní sektor, což je jeden ze základních rysů společensky odpovědného muzea. V prvním případě šlo o projekt $s$ přesahem do světa osamělých seniorů, $\mathrm{v}$ druhém př́ípadě do společnosti vyloučených jedinců ve věznicích a na třetím místě projekt, který cílí na místní komunity, které by samy do galerie jen těžko zavítaly, na jejich zapojení do života GASK a rozvoj jejich sociálních kompetencí.

24 Lektorské centrum GASK. In PINNOY, Věra. Galerie Středočeského kraje jako společensky prospěšná instituce. Brno: Masarykova univerzita, Filozofická fakulta, Ústav archeologie a muzeologie, 2017, s. 27-30. Bakalářská diplomová práce.

25 Více informací in Lektorské centrum GASK [online]. [cit. 2017-04-26]. Dostupný z www: <http://www.gask.cz/cs/navsteva/lektorskecentrum $>$.

\section{Místo v depozitáři aneb Depozitář je domovem seniorů pro obrazy. \\ Domov seniorů je depozitářem pro lidi.}

Projekt Ondřeje Horáka, tehdejšího vedoucího LC GASK, svým poněkud dlouhým, ale výstižným názvem velmi přesně vystihuje situaci, na kterou chce reagovat. Na jedné straně poukazuje na sbírkové fondy galerií, jejichž velkou část tvoří kromě odborníky ceněných děl také díla, jež dávno přestala být či nikdy ani nebyla součástí výstavních plánů a dlouhá léta leží v depozitáři bez jakéhokoliv přínosu pro veřejnost, na druhé straně potom na problém péče o naše blízké, kteří se mohou $\mathrm{v}$ domovech seniorů, bez ohledu na to, jak kvalitní péči a pestrý program dokáží tyto instituce nabídnout, cítit podobě jako tato „zapomenutá“ díla, jaksi odložení a nepotřební. LC GASK přišlo s myšlenkou „odloženým“ obrazům vrátit alespoň na nějaký čas smysl a „odloženým“ seniorům zase zpestřit čas a hlavně získat jejich zpětnou vazbu a probudit v nich vzpomínky a myšlenkové pochody, z nichž mělo vzejít nové samostatné umělecké dílo $v$ podobě videoartové prezentace, jež by toto téma otevřelo veřejnosti.

LC GASK projekt realizovalo $\mathrm{v}$ roce 2010 ve spolupráci s místním Domovem Barbora, poskytovatelem sociálních služeb určených seniorům formou celoročního pobytu. Realizace projektu obnášela převzetí osobního rizika, a to jak ze strany ředitele GASK, tak ředitelky Domova Barbora za bezpečnost „zapůjčených“ děl. Otázka bezpečnosti děl a hlavně převzetí zodpovědnosti se projevila i později jako jedna $\mathrm{z}$ největších překážek realizace podobných projektů. $\mathrm{V}$ tomto případě se všichni shodli na tom, že ponesou jistá rizika, aby projekt mohl být realizován. $Z$ depozitáře byla vybrána díla, jež se shodovala rokem svého vzniku s rokem narození seniorů zapojených do projektu. Záměrně, a to nejen $\mathrm{z}$ bezpečnostních důvodů, byla vybrána díla, která nejsou nejcennějším jádrem sbírkového fondu galerie. Ta se poté na 24 hodin přestěhovala na zdi pokojů seniorů na místo, které si přesně sami určili. Senioři pak byli po 24 hodin vystaveni konfrontaci se „stejně starými“ obrazy. Poté byly obrazy znovu svěšeny a po krátkém kurátorském výkladu navráceny zpět do depozitáře GASK.

Vzájemné prolínání příběhů seniorů se stejně starými obrazy a jejich reakce a vzpomínky zaznamenala na videozáznam umělkyně Eva Jiřička. $Z$ celé akce měl poté v GASK vzniknout samostatný výstavní projekt, kdy obrazy, zapůjčené do Domova Barbora, měly být instalovány spolu $s$ videozáznamy jejich výkladů očima seniorů. Videoartový dokument ani výstavní projekt už bohužel nebyly po odchodu týmu z GASK realizovány. Tento moment celé koncepce přitom považuji za velmi důležitý a společensky přínosný. Konfrontace pohledů velmi citlivě otevírá řadu aktuálních témat a otázek, a to nejen společenských, jako je náš postoj ke stáŕí, ale i např́íklad téma př́lišné ochrany uměleckých děl, která za těchto okolností může být i překážkou v jejich přínosu pro společnost. Díla, která za těchto okolností přinejmenším zpestřila čas osamělých starých lidí, v př́ípadě realizace celého projektu snad i ovlivnila názory a postoje návštěvníků galerie, by nebýt osobní odvahy několika lidí ochotných pro své přesvědčení překročit jisté hranice nařízení a řádů a přijmout určitá rizika, 
zůstala bez užitku nadále „odborně uskladněna“.

„Místo $v$ depozitáři“ otevírá velké možnosti modifikací do různých prostředí, mezi jednotlivce a komunity mimo galerii. Toto téma bylo předmětem i dalšího počinu Ondřeje Horáka a Martiny Rekové „Věznice: místo pro uměni“, u jehož zrodu stála právě zkušenost s realizací tohoto projektu.

\section{Věznice: místo pro umění Prison: No Limits for Art}

Přestože projekt „Věznice: místo pro uměni" nebyl celý realizován GASK, ${ }^{26}$ považuji za důležité ho do daného kontextu s laskavým svolením jeho autorů zařadit, nebot myšlenkově vzešel $\mathrm{z}$ výše popsaného projektu „Místo $v$ depozitáríi“, který téma sociálních kompetencí kulturních institucí v GASK otevřel, a na kterou nový tým LC GASK po čase navázal a dále ji rozvíjel komunitním projektem „Umění spojeni“.

Realizace projektu založeného na spolupráci vězňů s předními českými současnými umělci se sestávala ze tř́ hlavních částí: korespondenční hry autorů projektu s odsouzenými, společného tvůrčího procesu vězňů s umělci a následné výstavy jejich prací v Centru současného umění DOX v Praze a v Moravské galerii $v$ Brně.

Téměř roční přípravná fáze projektu zahrnovala především navázání spolupráce a konzultace $s$ jednotlivci i celými pracovními týmy z různých oblastí a zapojení dalších institucí (přizvání odborníků z oblasti metodiky pro

26 Projekt Ondřeje Horáka a Martiny Rekové „Věznice: místo pro umění“ vznikl a jeho přípravná fáze proběhla ještě na půdě GASK. Po odchodu původního týmu kvůli neshodě s novým vedením galerie byl však dokončen ve spolupráci s Centrem současného umění DOX a s Moravskou galerií, která kromě výstavních prostor poskytla k dispozici i svůj depozitáŕ. výkon vazby a trestu $\mathrm{z}$ Vězeňské služby ČR a z Mediační a probační služby ČR bylo zásadní už pro podobu samotné vize).

Cílem první realizační fáze projektu nazvané „Hra“, kterou vedli jeho autoři s účastníky formou korespondence, bylo představit odsouzeným životy umělců a nakonec i originály jejich děl. Přes třicet odsouzených ze sedmi zapojených věznic se během tříměsíčního dopisování pídilo na základě různých indicií v dopisech po jménu hledaného umělce. Hra byla koncipována s ohledem na omezené možnosti prístupu $\mathrm{k}$ informacím ve věznicích, kde odsouzení nemají přistup $\mathrm{k}$ internetu ani $\mathrm{k}$ potřebné literatuře. Až na výjimky všichni zúčastnění nakonec hledané autory objevili. Originály děl těchto autorů byly představeny s kurátorským výkladem prrímo ve věznicích. Tato možnost přesunu cenných originálů z jednoho nepřístupného prostoru do druhého, ještě více monitorovaného, vypovídá znovu o možnostech nadstandardní spolupráce $\mathrm{v}$ rámci státních institucí. Prakticky je to však velice náročné a projekt se $\mathrm{v}$ tomto bodě opět ocitl podobně jako $\mathrm{v}$ předchozím případě v ohrožení. Tentokrát ovšem ředitelé věznic odmítli převzít rizika spojená s bezpečností děl a na poslední chvíli nesouhlasili $s$ jejich převozem. Konfrontace odsouzených s originály děl autorů nakonec proběhla jen díky zásahu ministra spravedlnosti.

Druhá fáze projektu byla zaměřená na umělecký dialog a tvůrčí proces vězňủ s umělci. Na základě krátkých profilů vězňů vzniklo přes třicet tvůrčích dvojic ve složení umělec-odsouzený. Prostřednictvím korespondence se dvojice domlouvaly na společné tvorbě, jež vycházela $\mathrm{z}$ velké části ze současných uměleckých tendencí konceptuálního umění, malby, grafiky, sochařské tvorby, ale i práce inspirované graffiti nebo komiksem. Někteří umělci „svoje“ odsouzené během tvưrčího procesu navštěvovali i ve věznicích. Výsledky jejich společné práce byly poté prezentovány na konci roku 2011 v Centru současného umění DOX, na jaře roku 2012 se poté výstava $\mathrm{v}$ pozměněné podobě přesunula do Moravské galerie. Výstupy společné práce umělců a odsouzených, spolu s popisem tvůrčího procesu a jeho důležitých momentů jsou dobře zdokumentovány $\mathrm{v}$ katalogu k výstavě. ${ }^{27}$

Ze vzájemné spolupráce odsouzených a umělců vznikla díla s velkým potenciálem přivést pozorovatele $\mathrm{k}$ hlubšímu zamyšlení nad otázkami viny a trestu, současných forem represe, jejich nedostatků a ovlivnit jejich postoje. Velmi důležitým momentem celé akce je začlenění části děl do sbírek Moravské galerie, jímž projekt překonal rovinu jednorázové akce, která končí výstavou. Vzkaz, která díla bezesporu nesou, tak bude moci vyznít $\mathrm{v}$ rámci dalších kurátorských počinů i v budoucnosti.

Přestože projekt jednoznačně prokázal potenciál kulturních institucí na poli sociální inkluze na všech třech zmiňovaných úrovních, ${ }^{28}$ nese s sebou stejně jako všechny sociálně angažované

27 Věznice: Místo pro umění. Praha: Centrum současného umění DOX a Brno: Moravská galerie v Brně, 2011. 96 s. Katalog výstavy.

28 U jednotlivců přinesl pozitivní výsledky v podobě posílení sebeúcty a kreativity, získání nových dovedností a sebevědomí. Nabídl odsouzeným podporu a příležitost k osobnímu rozvoji, který jim často nebyl v jejich životě, at už z jakéhokoliv důvodu, umožněn. Na komunitní úrovni zapůsobil zejména ve smyslu podpory lidí, jejichž život je pobytem ve vězení už navždy stigmatizován, kdy společnost přes záznam v trestním rejstř́íku už nenahlíží skutečné, často nelítostné osudy odsouzených lidí. Na celospolečenské úrovni potom ve smyslu zapojení komunity odsouzených do života galerií, začlenění a prezentace jejich prací ve sbírkách, jež má potenciál šířit toleranci a vzájemný respekt, měnit postoje celé společnosti a napadat stereotypy 
projekty tohoto typu mnohá úskalî. ${ }^{29}$ Ondřej Horák zmiňuje jako jednu z hlavních stinných stránek celého počinu moment, kdy odsouzeným oznámili, že projekt skončil. Po půlroční intenzivní práci na dílech i na sobě samých a neobvyklé vlně zájmu a pozornosti ze světa „zvenku“, najednou přišel znovu zaběhnutý stereotyp vězeňského života, jenž nenabízí př́liš impulzů ke změně postojů či podnětů, které by je mohly iniciovat. Zde se nabízí otázka návaznosti práce samotných institucí, v tomto případě věznic, které by měly umět na impulzy tohoto typu reagovat, prijímat je a umět s nimi dál pracovat.

\section{Umění spojení}

Projekt „Umění spojeni““ byl od počátku vystavěn $s$ cílem navázat a prohloubit vztahy s místní komunitou, a to na několika úrovních. Předně šlo o otevření GASK skupinám, pro něž je $\mathrm{z}$ jakéhokoliv důvodu obtížné se do galerijních aktivit zapojit, a nechat je prostor galerie zažít jako bezpečné, přátelské a inspirativní místo. Na další úrovni potom zaangažovat a přizvat k aktivní spolupráci místní obchodní společnosti, neziskové organizace, zastupitele města a kraje a v neposlední řadě i zaměstnance GASK. Tato partnerská spolupráce spolu s kreativním prrístupem umělců, podpoře města a vstřícným postojem ze strany vedení galerie dala vzniknout velmi dynamické tř́leté akci, která pozitivně ovlivnila vztahy s místní komunitou, přivedla do galerie nové návštěvnické skupiny a významně také posunula další rozvoj společenského poslání GASK.

29 Spoluautor projektu Ondřej Horák a kurátor výstavy v Moravské galerii Ondřej Chrobák v rozhovoru pro časopis A2. STEJSKALOVÁ, Tereza. Spolupráce vyloučených. A2, 2012, č. 10 [online]. [cit. 2012-05-09]. Dostupný z www: <http://www.advojka.cz/archiv/2012/10/ spoluprace-vyloucenych $>$.

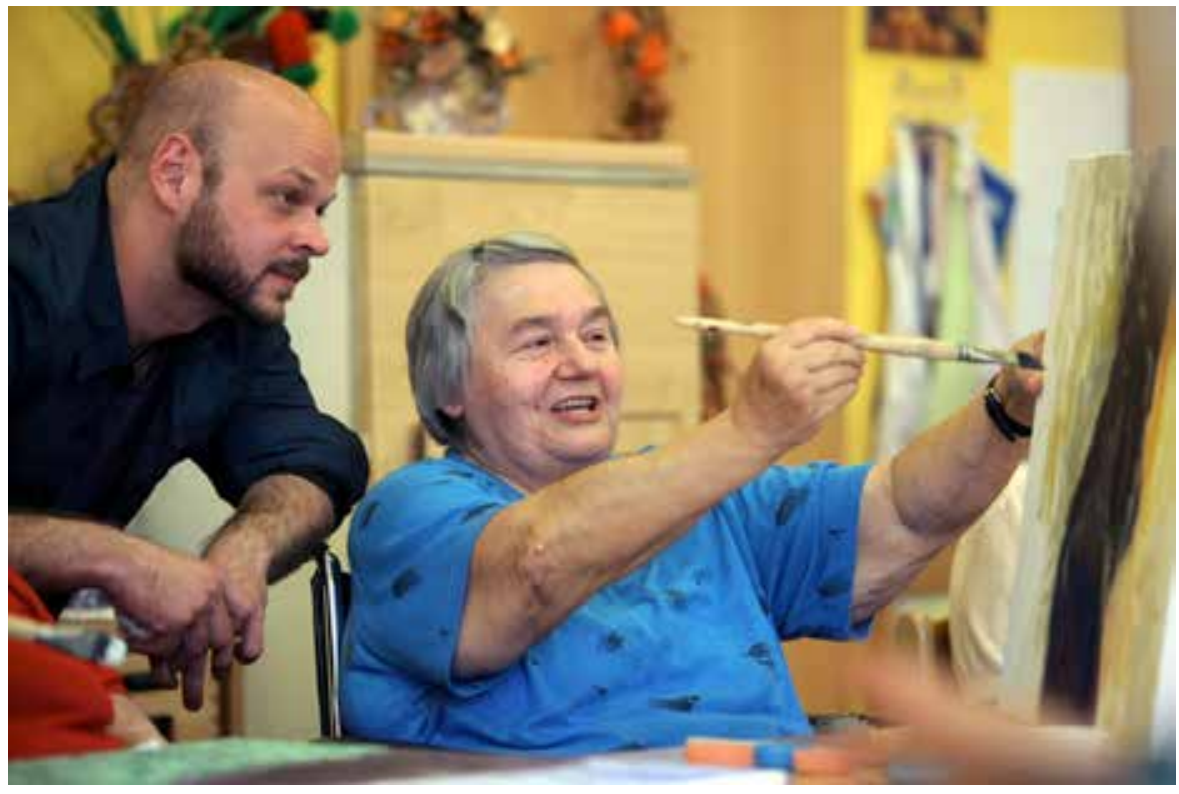

Obr. 1: Výtvarná dílna Pavla Vašíčka v Domově Barbora. Umění spojení 2013. Foto: Karel Šanda.

Základní konstrukce projektu spočívala ve spolupráci určité cílové skupiny s umělcem, který sám vytvořil koncept pro konečné dílo, jež ze společné práce vzešlo a stalo se předmětem benefiční aukce $\mathrm{v}$ závěru roku, přičemž získané finanční prostředky byly věnovány vybrané neziskové organizaci na předem stanovený účel. Při mapování potenciálních účastníků akce, tedy regionální sítě poskytovatelů sociálních služeb a dalších organizací pečujících či sdružujících lidi s různým typem znevýhodnění, byl první ročník projektu zaměřen na cílovou skupinu seniorů, druhý ročník poté na ,juniory“. Z tohoto rozvržení vzešla i myšlenka projevu mezigenerační solidarity, kdy finanční prostředky získané z prací seniorů byly věnovány na pomoc dětem a naopak ,junioři“ věnovali výsledky své práce osaměle žijícím starým lidem. Ve třetím ročníku se toto členění ukázalo jako poněkud limitující a od „podtitulü“ bylo upuštěno.

Během prvního ročníku projektu v roce 2013 se podařilo do společné práce s umělci zapojit celkem devět skupin seniorů. ${ }^{30}$ Každá z těchto akcí byla v některých ohledech výjimečná. ${ }^{31}$ Některé probíhaly prýímo na půdě GASK, jiné pro větší komfort seniorů přímo $\mathrm{v}$ institucích poskytujících péči. Obecně lze říci, že práce se skupinami seniorů se nesla ve velmi klidném, přátelském duchu a díky zapojení skupin „aktivních seniorü“ $\mathrm{z}$ řad Klubu důchodců, turistů a galerie získala nové publikum, které se pravidelně začalo objevovat na vernisážích, přednáškách a dalších akcích. Ze spolupráce se seniory, pro něž je věk už velmi limitujícím faktorem, si pořadatelé odnesli řadu postřehů a zkušeností. Velmi důležitá byla u této cílové skupiny spolupráce s odbornými pracovníky institucí ochotnými poskytnout cenné rady

\footnotetext{
30 Např. klienty Domova pro seniory Barbora v Kutné Hoře, seniory z Oblastní Charity, místní Klub důchodců, seniory z Klubu turistů ad.

31 Projekt včetně spolupráce jednotlivých umělců se skupinami a katalogu vzniklých děl je podrobně zmapován v Umění spojení. In PINNOY, Věra. Galerie Středočeského kraje jako společensky prospěšná instituce. Brno: Masarykova univerzita, Filozofická fakulta, Ústav archeologie a muzeologie, 2017, s. 40-56. Bakalářská diplomová práce; dále v Kutnohorské listy [online] na www: <http://www.kutnohorskelisty.cz/> pod heslem „Umění spojeni““ [cit. 2017-05-15] nebo na webových stránkách Lektorského centra GASK [online]. [cit. 2017-05-15]. Dostupný z www: <http://www.gask.cz/cs/lektorske-centrum/ umeni-spojeni-015>
} 
ohledně fyzických či psychických limitů svých klientů, které prri tvorbě programu člověk bez zkušeností často nedomyslí.

Druhý ročník „Umění spojeni““ realizovaný $\mathrm{v}$ roce 2014 s podtitulem ,junior" byl zaměřen především na cílovou skupinu dětí a mládeže se sociálním znevýhodněním. Ke společné tvorbě se podařilo přizvat deset umělců a skupin, mezi nimiž se často objevovaly děti a dospívající $\mathrm{z}$ romského etnika. Nově byla zapotřebí nejen úzká spolupráce s pracovníky zapojených institucí, ${ }^{32}$ ale i se zaměstnanci galerie, především $\mathrm{z}$ řad dozorců a ochranky, aby byli dostatečně informováni, pochopili podstatu projektu a přistupovali ke všem s respektem nebo alespoň nedávali najevo své negativní postoje. Druhý ročník byl v porovnání s prvním daleko náročnější na př́ípravu a zajištění hladkého průběhu akcí, a to zejména pro umělce bez pedagogických zkušeností. V programech, které nebyly doslova „nabité“ činností, vyžadovaly více koncentrace nebo obnášely technologické pauzy či stř́ídání jednotlivých účastníků u nějaké činnosti, se častěji projevila netrpělivost, ztráta pozornosti a zájmu. $\mathrm{V}$ těchto chvílích se vyplatilo mít v záloze nějaké vedlejší aktivity, krátké ukázky originálů děl ve stálé expozici souvisejících například tematicky s jejich aktivitou či drobné hádanky, hry a krátké programy, při kterých poznávaly prostory GASK. Jednotlivé akce vyžadovaly intenzivnější zapojení lektorek GASK a často i doprovodu jednotlivých skupin.

32 Např. klienti Klubu Kotva, zaměřeného na práci s rizikovou mládeží ohroženou sociálně patologickými jevy, dospívající klienti z nízkoprahového klubu Maják, děti ze Speciální školy v Kolíně, děti z ubytovny sociálně slabých v Lorci, děti z Dětského domova v Býchorech, dospívající z Výchovného ústavu Kutná Hora ad.

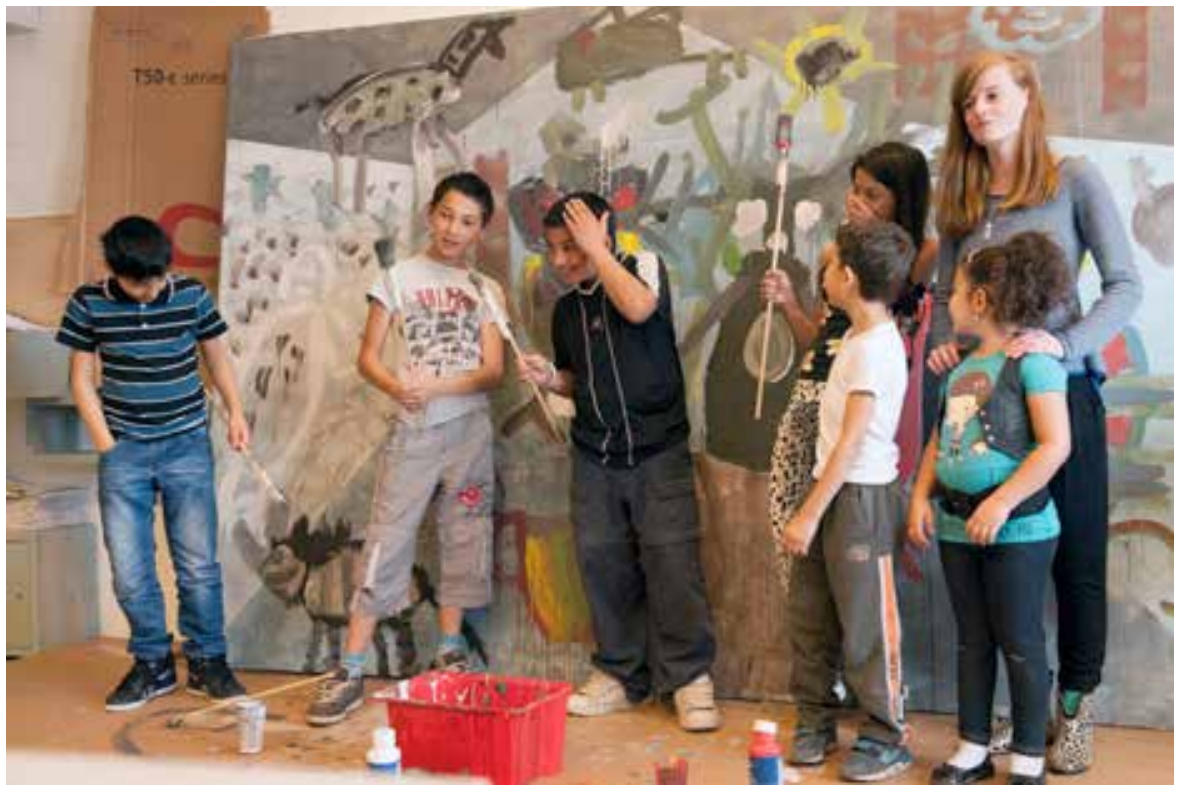

Obr. 2: Výtvarná dílna Kateřiny Drahošové v GASK. Umění spojení 2014. Foto: Marián Chachalák.

Třetí, finální ročník projektu těžil z kontaktů a zkušeností nabytých $\mathrm{v}$ předchozích dvou letech. Díky atmosféře akcí, kde se $\mathrm{k}$ práci uzavřené cílové skupiny, přidali i lidé z jiného prostředí, bylo upuštěno od zaměření na určitou cílovou skupinu. ${ }^{33} \mathrm{Ve}$ finálním ročníku projektu šlo tedy především o setkání různých lidí, různého věku, zdravotní kondice, sociálního postavení a prostředí, ze kterého pocházejí. K účasti byli přizváni studenti, skauti, senioři, umělci noví i již osvědčení, účastníci z minulých ročníků a další, kteří měli chut se zapojit. $\mathrm{V}$ tomto formátu se opět podařilo realizovat celkem deset výtvarných akcí.

Vyvrcholením všech tří ročníků byla v závěru každého roku vernisáž vzniklých prací spojená s benefiční aukcí, která vyžadovala náročnou přípravu

33 Toto rozhodnutí nás osvobodilo od často zavádějících názvů a označení jednotlivých skupin účastníků - jako senior, junior, člověk se zdravotním znevýhodněním, děti ze sociálně nepodnětného prostředí či riziková mládež ohrožená patologickými sociálními jevy ad. Termíny, které pro naše potřeby nebyly důležité, o lidech mnoho nevypovídají, pro běžnou veřejnost jsou spíše zavádějící a ani účastníci akcí se s těmito přívlastky často neztotožňovali. a koordinaci. Myšlenka využití duševního potenciálu lidí, kteří jsou ve většině prrípadů odkázáni na finanční pomoc státu, a propojení jejich úsilí se světem místních prosperujících firem a veřejnosti, která ho ocení nákupem vzniklých uměleckých děl, jež nebudou „klasickými charitativními výrobky“, ale díky zapojení umělců skutečně cennými díly, ještě s mezigeneračním přesahem vzájemné pomoci a zapojením třetího subjektu, kterému bude finanční výtěžek darován, nebyla snadná konstrukce $\mathrm{k}$ několikaminutové prezentaci, na kterou jsou firmy zvyklé. Zejména první ročník, bez reference na úspěšné benefice $\mathrm{z}$ minulých let, byl pro přesvědčování potenciálních dražitelů velmi náročný. $\mathrm{V}$ tomto směru pomohly vazby GASK vybudované ve sféře jejího komerčního působení, tedy pronájmu prostor $\mathrm{v}$ rámci pořádání různých firemních akcí a také zapojení zaměstnanců, kteří sami přinášeli tipy na potenciální dražitele. Přizvat ke spolupráci a získat podporu velkých 
nadnárodních firem, ${ }^{34} \mathrm{o}$ kterou bylo od počátku akce usilováno, se ukázalo jako dosti náročné. Všechny velké firmy budují svou společenskou odpovědnost dlouhodobě, na základě jasně dané vize a jen $\mathrm{v}$ určité oblasti, která je jejich prioritou. Přesto se podařilo již první rok získat na svou stranu jednoho ze tří místních „gigantưđ, díky jehož podpoře byla benefice již v prvním roce velmi úspěšná. TPCA nečerpalo finanční prostředky ze svých grantových programů, ale uspořádalo celozávodní zaměstnaneckou vánoční sbírku. Z jejího výtěžku zástupci firmy vydražili velkoformátové plátno, které nyní zdobí hlavní výrobní halu továrny. Druhým rokem se do benefiční akce zapojil velmi kreativním způsobem i výrobní závod FOXCONN. ${ }^{35}$ Aktivnímu zapojení velkých nadnárodních firem předcházela řada osobních schůzek a prezentací, při nichž byla vyjasněna pravidla vzájemné spolupráce, včetně jejich prezentace $v$ průběhu projektu a mediálních výstupů. Dobrým motivačním prvkem k zapojení nejen velkých podniků, ale všech dražitelů vůbec byl pozitivní př́nos na několika úrovních, který nákup díla způsobí. Nešlo jen o přímou podporu neziskové organizace, která finanční obnos obdrží, ale nákupem díla firma vyjádří podporu i účastníkům projektu a umělcům, kteří se na vzniku díla podíleli, posílí v místní komunitě atmosféru vzájemného respektu a sebeúctu lidí, jejichž životy jsou často již od počátku určovány obtížnými skutečnostmi, nelehkými podmínkami a komplikovaným rodinným zázemím. Kromě velkých firem bylo velmi důležité zapojit zástupce města a veřejnost. Prvním

34 Spoléhali jsme zejména na automobilku TPCA, výrobce spotřební elektroniky FOXCONN a výrobce cigaret Philip Morris.

35 Zaměstnanci firmy byli jejím vedením osloveni anketou, které dílo by se jim do vstupních prostor továrny nejvíce líbilo. Každý zaměstnanec, který přispěl do sbírky na dražbu obrazu, potom dosta odznáček s malým výsekem tohoto díla.

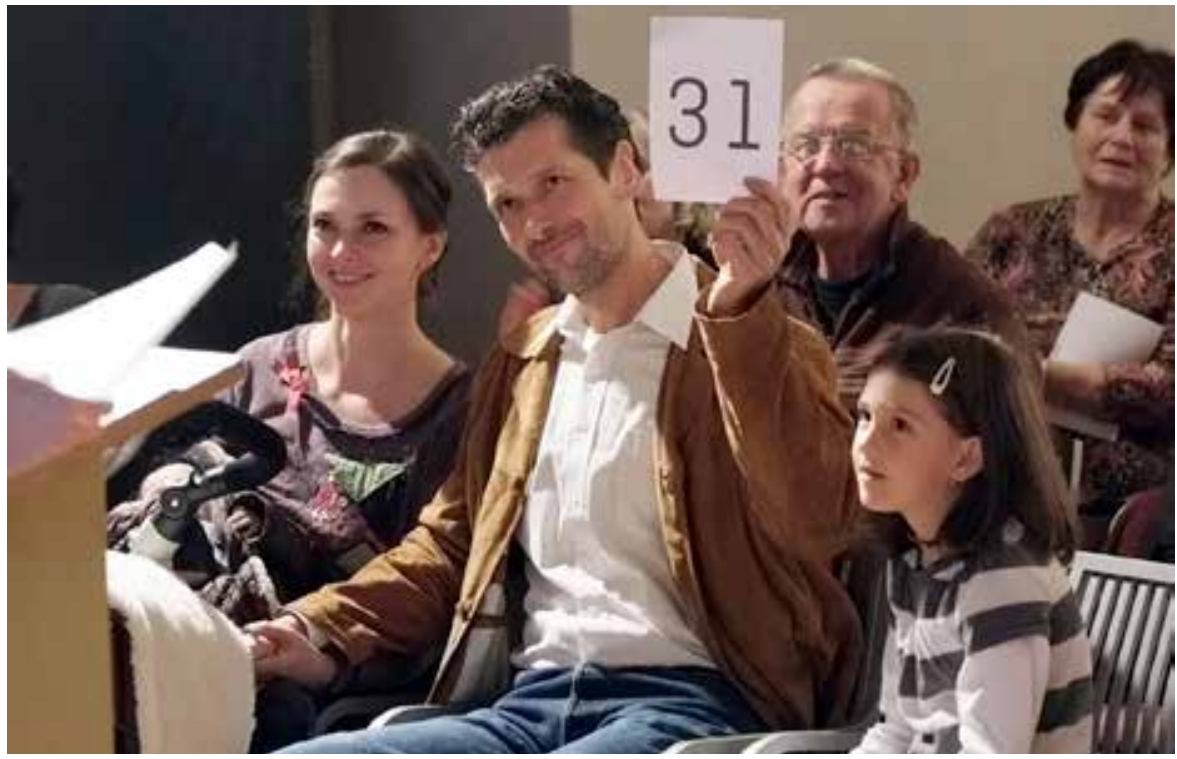

Obr. 3: Benefiční aukce Umění spojení v GASK v prosinci 2013. Foto: Jan Šmok.

rokem svou štědrostí a přístupem př́ijemně překvapila místní rodina, která na aukci vydražila společně se svými třemi dětmi dílo, jež posléze věnovala zpět jeho tvůrcům, seniorům z Domova Barbora. Stejně tak postupovali i v dalších ročnících. Jako důvod svého počínání uvedli, že chtějí svým dětem dát př́klad, jak zacházet správně s přebytečnými penězi. Tímto přístupem inspirovali $\mathrm{v}$ dalších letech ostatní rodiny, takže v posledním ročníku se při benefiční aukci strhala největší dražební bitva právě mezi dětmi, které hlasitým povzbuzováním rodiče vybízely $\mathrm{k}$ dalším příhozům. Také účast zástupců města nebyla jen formální, aktivní zapojení starosty města do dražby bylo pro další spolupráci a navázání bližšího kontaktu se zastupiteli města velmi cenné.

Pro úspěšnou realizaci podobné akce spatřuji jako nejdůležitější opět spolupráci a zdravé nadšení lidí, kteří se na projektu jakkoliv podílejí. V první fázi je nutné přesvědčit účastníky a umělce o smysluplnosti jejich práce a $v$ druhé fázi potom nadchnout pro projekt potenciální dražitele. Zde hrál velkou roli mimořádně stresující element nenaplněných očekávání a zklamání ze strany tvůrců děl, kteří byli při dražbě př́ítomni. Aby nedošlo k situaci, která by přinesla účastníkům projektu naprosto opačný psychologický efekt, než byl zamýšlen, muselo mít každé dílo svého dražitele. Okamžik, kdy by o dílo $\mathrm{v}$ přeplněném sále nikdo neprojevil zájem, by byl pro př́tomné tvưrce, zvláště děti ze sociálně slabých poměrů, dětských domovů a výchovných ústavů, velkým zklamáním. Tomu bylo zabráněno nejenom zajištěním kupce na každou položku, ale $\mathrm{v}$ případě velkých částek i zinscenováním dražebního boje, aby celá akce působila na všechny zúčastněné naprosto autenticky. ${ }^{36}$ Ve třech ročnících projektu se podařilo vydražit celkovou částku přes tři čtvrtě milionu, která byla rozdělena mezi tř̌i neziskové organizace $\mathrm{v}$ regionu. ${ }^{37}$ Získaný

$36 \mathrm{~V}$ tomto směru je velmi důležitá osobnos licitátora, v prŕípadě GASK herečky Hanky Malaníkové, která zvládla celý večer udržet výjimečnou atmosféru a zdůraznit mimořádné okamžiky. Díky jejímu výkonu se čím dál častěji objevovaly i „nesjednané“ příhozy, takže nakonec dílo často skončilo $\mathrm{v}$ rukou jiných než „domluvených“ dražitelů.

37 První rok senioři darovali finanční obnos Stř̌edisku rané péče, jež poskytuje pomoc rodinám pečujícím o děti s handicapem. Druhý 
finanční obnos ve výsledku ovšem nebyl prioritou projektu, i když pro jeho účastníky, podpořené organizace a $v$ neposlední ŕadě i pro média a širokou veřejnost byl dosti podstatný. Jasně uchopitelná komunikovatelná věc, které každý rozumí. Stěžejním momentem celého počinu byla chvíle, kdy se účastníci projektu ocitli v roli pomáhajících obklopeni respektem všech přítomných. Tento moment byl i ze zpětné vazby prítomných vychovatelů a pečovatelů vyhodnocen jako vrchol celého projektu.

\section{Přes jednoznačně převažující} pozitiva je nutné zmínit i některá z úskalí projektu, na prvním místě nutnost týmové práce a $\mathrm{v}$ opačném případě nebezpečí „,vyhoření“, pokud se projekt stane záležitostí jednoho člověka. Realizace projektu klade nároky na velmi různorodou agendu. Je nutné se dobře zorientovat $\mathrm{v}$ oblasti ziskové i neziskové sféry $\mathrm{v}$ daném regionu, aby mohlo dojít k smysluplnému propojení jejich potenciálu a naplnění očekávání, jež jsou v zásadě velmi odlišná. ${ }^{38}$ Dále je nutné velmi poctivě a profesionálně zpracovávat PR celého projektu. ${ }^{39}$ Zcela specifickým úsekem realizace

rok vydraženou částku naopak „děti“ věnovaly organizaci Život 90 pečující o osaměle žijící

seniory na nákup signalizačních zařízení

k rychlému přivolání pomoci. Ve třetím ročníku propojujícím všechny účastníky, byly získané

finanční prostředky využity na počáteční fázi

obnovy zanedbané lokality Sklenářova dolíku,

jenž se v duchu projektu stane místem procházek,

relaxace a společného setkávání lidí bez ohledu na

věk, zdraví či sociální postavenî.

38 Spolupracujícím organizacím z oblasti neziskové sféry, tedy účastníkům projektu je nutné věnovat hodně času, konzultovat s nimi připravované dílny, pomáhat umělcům při jejich realizaci a poskytovat si oboustrannou zpětnou vazbu, která často vede k navázání užší spolupráce i mimo rámec projektu. Pro ziskovou oblast je naopak nutné v co nejkratším čase

dokázat efektivní prezentací přesvědčit zástupce společností o smysluplnosti a přínosech jejich zapojení.

39 Vydávat tiskové zprávy, spolupracovat zejména s regionálním tiskem, aktualizovat webové stránky a facebookového profilu projektu, šírit povědomí o projektu i prostřednictvím webových stránek zapojených organizací a obchodních společností. je potom velmi náročná příprava benefičního večera, která obnášela vlastní agendu, jež vyžadovala podporu a pomoc celého týmu, který kromě organizační podpory přinesl do projektu další podněty, kontakty a nápady. Dalším úskalím je v případě každoročního opakování nebezpečí vyčerpání a vytěžení energie, kterou s sebou projekt přináší. Během plánovaných tří let jeho trvání se podařilo nadchnout jistý okruh lidí a dosáhnout jakéhosi „vrcholu“ pozitivních emocí spojených s myšlenkou vzájemné pomoci a podpory realizované touto formou. Další pokračování ve stejném formátu by časem přineslo jakési opotřebení a postupný úpadek. Je nutné si neustále uvědomovat a jasně prezentovat hlavní myšlenku celého úsilí, jež se velmi snadno pro mnohé posune pouze $\mathrm{k}$ výši vybrané finanční částky a očekávání jejího každoročního růstu. Pro LC GASK byla prostředkem $\mathrm{k}$ uskutečnění jiných cílů. I z tohoto pohledu je nutné po určité době projekt transformovat do jiné podoby, v případě GASK do podoby dlouhodobého nastavení celé instituce, jež se pod názvem „GASK bez bariér" bude ve spolupráci s místními komunitami nadále snažit o rozvoj svého společenského poslání.

\section{GASK bez bariér}

„GASK bez bariér“ je tedy přirozeným vyústěním projektu „Umění spojeni" a představuje další fázi rozvoje společenského poslání GASK. Nejde již o dílčí projekt, ale spíše dlouhodobé nastavení celé instituce, kdy dojde $\mathrm{k}$ transformaci a zapracování myšlenek „Umění spojení“ do běžné praxe. Velkým úskalím sociálních projektů je nenávaznost, která často ponechá oslovené, motivované účastníky po skončení projektu v jakémsi vzduchoprázdnu. Na této rovině GASK bez bariér pokračuje ve spolupráci s organizovanými skupinami návštěvníků se specifickými potřebami navázané $\mathrm{v}$ průběhu realizace „Umění spojeni" ", 40 kterou definuje v memorandech. ${ }^{41}$

\section{V koncepci „GASK bez bariér“ se} galerie mimo jiné znovu vrací také k cílové skupině nevidomých a slabozrakých návštěvníků. ${ }^{42}$ Novým počinem $\mathrm{v}$ rámci koncepce je zavedení nového programu s názvem „Stavy mysli bez bariér," který se váže ke stálé expozici Stavy mysli/Za obrazem. Jde o komentované prohlídky jednotlivých dvojic „stavů mysli,“ pro skupiny návštěvníků, které se běžných komentovaných prohlídek, at' už z jakýchkoliv důvodi̊, nemohou účastnit. Oslovuje zejména rodiče, kteří mají pocit, že s malými dětmi nejsou v kulturních institucích na programech určených pro dospělé vítáni, zvláště pokud jejich dítě není ještě zralé na samostatný pobyt $\mathrm{v}$ dětském koutku pod dohledem cizí osoby. Možnost hlídání v dětském koutku je během programu také $\mathrm{k}$ dispozici, ale primárně se počítá s účastí malých dětí při výkladu. Na základě pozitivních ohlasů a také poptávce samotných účastnic, byl program obohacen o výtvarnou dílnu nazvanou „Když jdou děti spát,“ která navazuje a tematicky vychází z již uskutečněných komentovaných prohlídek a probíhá ve večerních hodinách po zavírací době galerie.

40 V současné době pokračuje aktivní spolupráce s Praktickou školou v Kutné Hoře a Kolíně, Klubem seniorů v Kutné Hoře, Diakonií Čáslav, Ubytovnou pro sociálně slabé občany v Lorci, Dětským domovem v Býchorech a Výchovným ústavem v Kutné Hoře.

41 Na základě podpisu tohoto memoranda se GASK a daná organizace dohodly na oboustranně prospěšné spolupráci v rámci projektu „GASK bez bariér", která nabízí klientům organizace nový impuls ve volnočasové a vzdělávací oblasti. V rámci memoranda jsou stanoveny podmínky vzájemné spolupráce, realizace návštěv a programů, platby a jeho účinnost.

42 GASK bez bariér. In PINNOY, Věra. Galerie Středočeského kraje jako společensky prospěšná instituce. Brno: Masarykova univerzita, Filozofická fakulta, Ustav archeologie a muzeologie, 2017, s. 56-57. Bakalářská diplomová práce. 
Do budoucna bude tento formát otevřen i dalším cílovým skupinám potenciálních návštěvníků, pro které je bariérou běžná otevírací doba, či celodenní péče o své blízké, nejenom děti.

V současné fázi rozvoje společenského poslání GASK je důležité posunout optiku nahlížení začleňování návštěvníků se specifickými potřebami z roviny integrace do inkluzivní roviny, tedy vnímat muzejní publikum jako ,jeden svět" s citlivým respektem vůči odchylkám od průměru. $\mathrm{V}$ tomto směru je žádoucí do budoucna vytvářet programy se zaměřením na celek, veřejnost jako takovou, samozřejmě s využitím nutných korekcí znevýhodněným návštěvníkům, jež ovšem nedělí muzejní publikum na dva světy - návštěvníci bez znevýhodnění (většinové publikum) a znevýhodnění návštěvníci (menšinové publikum) ${ }^{43} \mathrm{k}$ čemuž tvorba speciálních programů podle charakterů jednotlivých znevýhodnění, ač nechtěně, přispívá. Dalším důležitým úkolem je, aby se vize společensky přínosného muzea stala společnou vizí celé instituce, nejenom Lektorského centra. V tomto směru jsou důležitá nejenom školení typu jak vystupovat v kontaktu s návštěvníky s různým typem znevýhodnění, ale hlavně, aby každý pracovník galerie tento společný záměr pochopil, ztotožnil se s ním a prozkoumal polohu společensky odpovědného přístupu v kontextu svojí práce, popřípadě se zamyslel nad eventuálními novými přístupy a postoji, jež $\mathrm{k}$ takovému směřování mohou pomoci. Další výzvou zůstává šíření hodnot společensky přínosného muzea, jako jsou sociální pohoda, rovnoprávnost, spravedlnost, boj proti diskriminaci a intoleranci

43 JAGOŠOVÁ, Lucie. Muzea a sociální inkluze. In Muzea a sociálně znevýhodnění: Sborník ze semináře 19.-20. 6. 2013. Hodonín: Masarykovo muzeum v Hodoníně, 2014, s. 23. nejenom v kulturním sektoru, ale i mimo něj. To se do značné míry dařilo naplňovat v projektu „Umění spojeni“ díky benefiční aukci, která propojila nekonvenčním způsobem velmi odlišné světy umění, byznysu, politiky a neziskového sektoru a dala jim možnost participovat na konkrétním společném záměru. Tento prvek zatím vzhledem k momentálním možnostem a kapacitě nyní nekompletního týmu ${ }^{44}$ vypadl. Do budoucna se ovšem jistě počítá $\mathrm{s}$ jeho oživením $\mathrm{v}$ novém formátu, založeném na praxi participace, sdílení zkušeností a rozvoji vztahů mezi galerií a komunitami mimo ni.

\section{Závěr}

Tato práce se ztotožňuje se závěry Výzkumného centra pro muzea a galerie při Škole muzejních studií Leicesterské univerzity ve Velké Británii, že muzea a galerie mají společenskou odpovědnost a potenciál přispívat $\mathrm{k}$ sociální inkluzi jednotlivců i celých komunit a inkluzivním přístupem pozitivně ovlivňovat názory a postoje celé společnosti. Cestou k dosažení těchto cílů je zejména interpretace sbírek novým způsobem, který zohlední i znevýhodněné skupiny a komunity, a zavedení inkluzivních postupů do klíčových oblastí muzejní práce. Společensky zodpovědné muzeum se i nadále zabývá sběrem, dokumentací, prezentací a interpretací sbírek, činí tak ale se záměrem, který prrímo souvisí s jeho pozicí ve společnosti. Ohniskem jeho koncepce je vztah $\mathrm{k}$ jednotlivcům a komunitám mimo muzeum. Lektorské centrum Galerie Středočeského kraje v Kutné Hoře jako jedna ze stěžejních pozic uskutečňování inkluzivního přístupu a společenského poslání galerie aplikuje tyto postupy do muzejní praxe od svého založení,

44 Čerpání rodičovské dovolené a to zejména prostřednictvím tří projektů zaměřených na spolupráci s místní komunitou a vyloučenými skupinami, které se svou koncepcí vymykají dnes již běžným způsobům zohlednění různých forem znevýhodnění a speciálních potřeb návštěvníků. První z nich z dílny Ondřeje Horáka „Místo $v$ depozitáŕi aneb Depozitáŕ je domovem seniorů pro obrazy. Domov seniorů je depozitárem pro lidi“ na jedné straně poukazuje na odborníky neoceňovaná umělecká díla, jež tvoří velkou část galerijních fondů a bez jakéhokoliv přínosu pro veřejnost leží „zapomenutá“ v depozitářích, na druhou stranu potom na problém péče o naše blízké, kteří se mohou v domovech seniorů často cítit podobně, jaksi odložení a nepotřební. Velmi originálně tyto dva „depozitáře“ propojuje a nabízí možnost neotřelého výstupu pro širší veřejnost v podobě galerijní výstavy. Druhý projekt Ondřeje Horáka a Martiny Rekové „Věznice: místo pro umění“ otevírá prostřednictvím umění téma zločinu a trestu a vztahu společnosti $\mathrm{k}$ vyloučeným a trestaným jedincům. Stěžejní část textu je potom věnována projektu „Umění spojení,“ který navázal a prohloubil vztahy s místní komunitou, nekonvenčním způsobem propojil velmi odlišné světy umění, byznysu, politiky a neziskového sektoru a dal jim možnost participovat na společném záměru v podobě konkrétní pomoci vybrané neziskové organizaci v regionu. Projekt nejenom potvrzuje sociální kompetence galerie, ale také řeší problém návaznosti podobných aktivit po jeho ukončení. V současné době má jako jediný ambici projít transformací do podoby stálého elementu a dlouhodobého nastavení celé instituce, jež pod názvem „GASK bez bariér“ nadále spolupracuje s účastníky uzavřeného projektu a snaží se 
o další rozvoj společenského poslání GASK.

\section{SEZNAM POUŽITÝCH PRAMENŮ A LITERATURY:}

BERGMANOVÁ, Marie. Sbírka 123 (Stopy historie $v$ akvizicích). Kutná Hora:

Galerie Středočeského kraje, 2010. 301 s. Katalog výstavy. ISBN 978-80-7056-161-4.

DODD, Jocelyn. The socially purposeful museum. Museologica Brunensia, 2015, č. 2, s. 28-32. ISSN 1805-4722.

DODD, Jocelyn a Richard SANDELL. Including museums: perspectives on museums, galleries and social inclusion [online]. Leicester: University of Leicester, Department of Museum Studies, 2001 [cit. 2017-05-05]. Dostupný z www: <https://www2.le.ac. uk/departments/museumstudies/rcmg/ projects/small-museums-and-socialinclusion/Including\%20museums.pdf $>$.

DRURY, Richard. Stavy mysli - Za obrazem (Stavy mysli). Kutná Hora: GASK - Galerie Středočeského kraje, 2014. 207 s. Katalog výstavy. ISBN 978 -80-7056-166-9.

JAGOŠOVÁ, Lucie. Muzea a sociální inkluze: Muzea a bariéry. In Muzea a sociálně znevýhodnění: Sborník ze semináře 19.-20. 6. 2013. Hodonín: Masarykovo muzeum v Hodoníně, 2014, s. 20-34. ISBN 987-80-87375-08-2.

JAGOŠOVÁ, Lucie, Vladimír JU゚VA a Lenka MRÁZOVÁ. Muzejní pedagogika: Metodologické a didaktické aspekty muzejní edukace. 1. vyd. Brno: Paido, 2010. 298 s. ISBN 978-80-7315207-9.

JANES, Robert R. Museums in The troubled world [online]. Oxon, 2009, s. 94 [cit. 2017-04-02]. Dostupný z www: $<$ http://s3-euw1-ap-pe-ws4-cwsdocuments.ri-prod.s3.amazonaws. com/9781138906372/2._Its_a_Jungle_in Here.pdf>. ISBN 0-203-87745.

KESNER, Ladislav. Marketing a managment muzeí a památek. 1. vyd. Praha: Grada Publishing, 2005. 304 s. ISBN 80-247-1104-4.

MAREŠ, Petr a Tomáš SIROVÁTKA. Sociální vyloučení (exkluze) a sociální začleňováni (inkluze) - koncepty, diskurz, agenda [online]. Praha: Sociologický ústav AV
ČR, 2008, s. 271-294 [cit. 2017-05-02]. Dostupný z www: <http://www. inkluzivniskola.cz/sites/default/files/ uploaded/Socialni_vylouceni_exkluze_a_ socialni_zaclenovani_inkluze.pdf $>$.

MÜLLEROVÁ, Magdalena, Ondřej KAŠPÁREK a Věra FRAJTOVÁ. Umělci pro společnost: Př́klady kulturních projektů $v$ oblasti sociální inkluze. 1. vyd. Praha: Česká kancelář programu Culture nákladem Institutu umění - Divadelního ústavu, 2010. 88 s. ISBN 978-80-7008$-249-2$.

Museum studies: RCMG. In University of Leicester [online]. [cit. 2017-03-22]. Dostupný z www: <http://www2.le.ac. uk/departments/museumstudies/rcmg>. PINNOY, Věra. Galerie Středočeského kraje jako společensky prospěšná instituce. Brno: Masarykova univerzita, Filozofická fakulta, Ústav archeologie a muzeologie, 2017. 74 s. Bakalářská diplomová práce. Vedoucí práce Mgr. Lucie Jagošová, DiS.

STEJSKALOVÁ, Tereza. Spolupráce vyloučených. A2, 2012, č. 10 [online]. [cit. 2017-05-02]. Dostupný z www: <http://www.advojka.cz/ archiv/2012/10/spoluprace-

-vyloucenych $>$.

ŠEBOROVÁ, Silvie. Kde je místo pro umění? Arttalk Magazine, 2012 [online]. [cit. 2017-04-10]. Dostupný z www: <http:// artalk.cz/2012/04/10/kde-je-misto-pro-umeni/>.

Věznice: Místo pro umění. Praha: Centrum současného umění DOX a Brno: Moravská galerie v Brně, 2011. 96 s. Katalog výstavy. ISBN 978- 80-87446-11-9 (DOX), ISBN 978- 80-7027-242-8 (MG).

WALKER, Alan a Carol WALKER. Britain Divided: The Growth of Social Exclusion in the 1980s and 1990s. London: Child Poverty Action Group, 1997. 308 s. ISBN 0-946744-91-6.

\section{VĚRA PINNOY}

Galerie Středočeského kraje (GASK) Kutná Hora, Česká republika pinnoy@gask.cz

Věra Pinnoy vystudovala obor sociální práce na VOŠ sociálně právní v Praze. V rámci studia muzeologie na Filozofické

fakultě Masarykovy univerzity v Brně se nyní zabývá tématem společenského poslání

kulturních institucí, zejména

inkluzí znevýhodněných skupin návštěvníků a rovným přístupem ke kultuře.

Po ukončení studia pracovala v Dětském domově v Semilech, od roku 2004 pro Nadaci Divoké husy v Praze. Od roku 2011 je v týmu Lektorského centra GASK v Kutné Hoře, kde od roku 2013 realizuje projekt Umění spojení a podílí se na strategii rozvoje společenského poslání GASK, zejména $\mathrm{v}$ oblasti nabídky kulturních a vzdělávacích aktivit se zohledněním různých

forem znevýhodnění a speciálních potřeb návštěvníků a odstraňování možných bariér přístupu.

Věra Pinnoy studied social work at the Vocational School of Social Work and Law, Prague and museology at the Faculty of Arts, Masaryk University in Brno, specializing in the social role of cultural institutions, especially the inclusion of underprivileged visitors and equal access to culture. After graduation she worked in a children's home in Semily, and from 2004 for the Wild Goose Foundation in Prague. She is a member of the GASK's Lecture Centre team (since 2011) where she started to implement the project The Art of Connection in 2013 and where she also participates in the strategy for the development of the social role of the GASK, notably in the field of cultural and educational activities in regard to different forms of visitors disabilities and special needs, and to the elimination of barriers in approaching these groups. 